\title{
Bulimia and Attention Deficit Hyperactivity Disorder (ADHD), the role of the stimulant in the treatment of Bulimia
}

\author{
V. Froes ${ }^{1}$, H. Afonso ${ }^{1}$, F. Leandro'1, I. Varela1', S. Esteves ${ }^{1}$, M. Carneiro ${ }^{1}$, Z. Gameiro ${ }^{1}$ \\ 1. Centro Hospitalar Barreiro Montijo, Psychiatry, Barreiro, Portugal
}

Objective

Our objective is it to evaluate which are the benefits of using a stimulant in the treatment of Bulimia.

\section{Materials and methods}

A non systematic literature search was performed in pubmed, medline and uptodate, using the key words "ADHD and Bulimia", "Stimulants and Bulimia", "Lisdexamfetamine and Bulimia".

\section{Introduction}

- Attention deficit hyperactivity disorder (ADHD) is a neurodevelopmental disorder that is associated with many comorbidities, including eating disorders (EDs). (Ptacek et al 2016)

- Evidences from modern neurobiology methods corroborate the abovementioned findings. For example, the Catechol- O-methyltransferase gene, involved in the dopaminergic pathways of ADHD, was also implicated in Bulimia Nervosa (BN). (Vilmaz 2011)

- From a neuroimaging perspective, $\mathrm{ADHD}$ and BN share many neural pathways. Abnormalities in these pathways in the frontostriatal circuit may account for the coincidences in these two disorders. (Broft 2012)

- The BN patients showed hyperactivation in parieto-occipital regions and reduced deactivation of default-mode-network (DMN) areas during alerting compared with healthy controls. Conversely, BN patients showed hypoactivation during reorienting and executive attention in anterior cingulate regions, the temporo-parietal junction (TPJ) and parahippocampus compared with HCs, which was negatively associated with global ADHD symptoms and impulsivity, respectively. (Seitz 2016)

- Low striatal DA in BN may impair the ability of patients to make use of alternative reinforcers to binge eating and/or purging.

\begin{tabular}{|c|c|c|c|c|c|c|}
\hline Reference & Male/female & Age & $\begin{array}{l}\text { BN } \\
\text { diagnosed at } \\
\text { the age of: }\end{array}$ & $\begin{array}{l}\text { ADHD } \\
\text { diagnosed at } \\
\text { the age of: }\end{array}$ & Treatment & Follow up \\
\hline \multirow[t]{3}{*}{ Drimmer E. 2003} & female & 42 & 20 & 39 & Methylphenidate $40 \mathrm{mg} /$ day & $\begin{array}{l}\text { Substantial decrease in } \\
\text { bingeing and purging } \\
\text { in } 3 \text { weeks }\end{array}$ \\
\hline & female & 31 & 16 & 31 & $\begin{array}{l}\text { Levoamphetamine }+ \\
\text { dextroamphetamine } 30 \mathrm{mg} / \text { day }\end{array}$ & $\begin{array}{l}\text { Substantial decrease in } \\
\text { bingeing and purging } \\
\text { in } 3 \text { weeks }\end{array}$ \\
\hline & female & 21 & 18 & - & Dextroamphetamine $10 \mathrm{mg} /$ day & Full remission in a week \\
\hline \multirow[t]{6}{*}{ Dukarm C. 2005} & female & 19 & 16 & 19 & Dextroamphetamine $15 \mathrm{mg} /$ day & Full remission in 2 weeks \\
\hline & female & 18 & 16 & childhood & Dextroamphetamine $15 \mathrm{mg} /$ day & $\begin{array}{l}\text { Full remission in } \\
15 \text { months }\end{array}$ \\
\hline & female & 21 & 16 & 21 & Dextroamphetamine $15 \mathrm{mg} /$ day & 2 years of full remission \\
\hline & female & 24 & 15 & 24 & Dextroamphetamine $15 \mathrm{mg} /$ day & $\begin{array}{l}\text { Substantial decrease in } \\
\text { bingeing and purging }\end{array}$ \\
\hline & male & 15 & 14 & 11 & Dextroamphetamine $30 \mathrm{mg} /$ day & Full remission in a week \\
\hline & female & 17 & 16 & 17 & Dextroamphetamine $30 \mathrm{mg} /$ day & $\begin{array}{l}\text { Substantial decrease in } \\
\text { bingeing and purging }\end{array}$ \\
\hline loannidis K. 2013 & female & 23 & 17 & 23 & Methylphenidate $18 \mathrm{mg} /$ day & $\begin{array}{c}\text { Substantial decrease in } \\
\text { bingeing and purging in } 2 \\
\text { weeks }\end{array}$ \\
\hline \multirow[t]{5}{*}{ Keshen A. 2013} & female & 34 & 16 & 34 & $\begin{array}{l}\text { Levoamphetamine }+ \\
\text { dextroamphetamine } 40 \mathrm{mg} / \text { day }\end{array}$ & $\begin{array}{c}\text { Full remission of bingeing } \\
\text { and purging }\end{array}$ \\
\hline & female & 20 & 15 & 20 & $\begin{array}{c}\text { levoamphetamine }+ \\
\text { dextroamphetamine } 40 \mathrm{mg} / \text { day }\end{array}$ & $\begin{array}{l}\text { Substantial decrease in } \\
\text { bingeing and purging }\end{array}$ \\
\hline & female & 23 & 18 & 23 & $\begin{array}{c}\text { levoamphetamine }+ \\
\text { dextroamphetamine } 40 \mathrm{mg} / \text { day }\end{array}$ & $\begin{array}{l}\text { Full remission of bingeing } \\
\text { and purging }\end{array}$ \\
\hline & female & 22 & 14 & 22 & $\begin{array}{c}\text { levoamphetamine }+ \\
\text { dextroamphetamine } 20 \mathrm{mg} / \text { day }\end{array}$ & Significant improvement \\
\hline & female & 32 & 16 & 32 & dextroamphetamine $20 \mathrm{mg} /$ day & $\begin{array}{l}\text { Substantial decrease in } \\
\text { bingeing and purging }\end{array}$ \\
\hline
\end{tabular}

\section{Conclusions}

Stimulants seem a promising therapy in Bulimia. However, based on these case reports, no statistic conclusions can be taken. It is still needed controlled trials to explore the efficacy and safety of psychostimulants as a treatment for this condition.

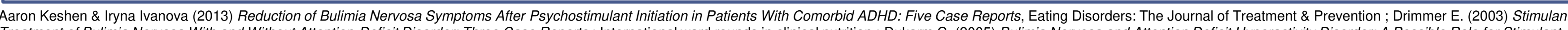

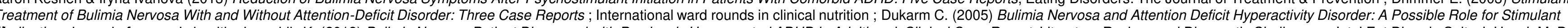

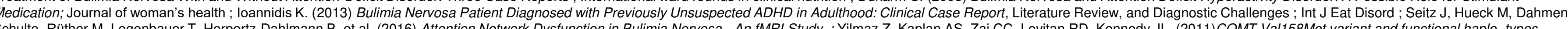

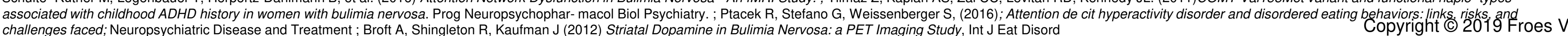

